\title{
THE RELATIONSHIP BETWEEN NEPOTISM AND DISENGAGEMENT: THE CASE OF INSTITUTIONS IN ETHIOPIA
}

\section{DOI: 10.17261/Pressacademia.2020.1197 \\ RJBM-V.7-ISS.1-2020(5)-p.53-65}

\section{Juneydi Woliye Kawo ${ }^{1}$, Alev Torun ${ }^{2}$}

${ }^{1}$ Marmara University, Department of Business Administration, Istanbul, Turkey. juneydiwk@gmail.com , ORCID: 0000-0003-4296-3940

${ }^{2}$ Marmara University, Department of Business Administration, Istanbul, Turkey. atorun@marmara.edu.tr, ORCID: 0000-0002-4205-4176

Date Received: January 8, 2020

Date Accepted: March 28, 2020

\section{To cite this document}

Kawo, J.W., Torun, A. (2020). The relationship between nepotism and disengagement: the case of institutions in Ethiopia. Research Journal of Business and Management (RJBM), V.7(1), p.53-65.

Permanent link to this document: http://doi.org/10.17261/Pressacademia.2020.1197

Copyright: Published by PressAcademia and limited licenced re-use rights only.

\section{ABSTRACT}

Purpose- This article examines the relationship between nepotism and employee disengagement across Ethiopian organizations. In organizations where nepotism is widely experienced, employee recruitment and promotion cannot be performed fairly. Therefore, individual and organizational competence would be under question which in turn may result in an unfair work environment. Consequently, employees may be alienated from work. The purpose of this study was hence to examine the relationship between the constructs of nepotism and disengagement in the organizations of Ethiopia as a developing country.

Methodology- A total of 255 employees were ( $M=202$ and $F=53)$ conveniently selected and made to fill the questionnaire in a face to face and online fashion. Nepotism and Disengagement scales were used to measure the variables. All of the variables were measured by scales with six-point intervals.

Findings - The factor analyses revealed that nepotism has two factors: nepotistic relationships and preferential policy. Disengagement turned out to be a uni-directional construct. The regression analysis revealed that nepotistic relationships significantly and positively contributed to disengagement whereas preferential policy did not significantly contribute to disengagement.

Conclusion-Since the participants perceived nepotistic relationships at work, the resulting employee disengagement is a potential threat for the future of organizations in terms of interpersonal relationships and performance. For preventing possible multi-faceted organizational problems that can affect the efficiency of business activities, managerial intervention seems to be required.

Keywords: Nepotism, Nepotistic Relationships, Disengagement, Negative Consequences, Ethiopia. JEL Codes: D23, M1, J71

\section{INTRODUCTION}

Corruption is widely seen as one of the biggest barriers to economic growth, investment, and poverty reduction in most developing nations. The World Bank defines corruption as making use of public property or assets for personal benefit (Campos and Pradhan, 2007). Corruption has several faces: bureaucratic corruption, nepotism and patronage, and state capture (Plummer, 2012). It comprises of bribery, nepotism, fraud, and extortion (Özler and Büyükarslan, 2011). Corruption is widely seen in most developing countries due to suitable conditions for it to happen in such a society (Ahmadi, 2009).

In various communities, socio-economic conditions lead the individuals to collaborate and cope up with their problems. Doing tasks in groups can alleviate the problems existing in the group, organization or the community besides resolving individual needs; yet merit has been considered as one of the most important factors which affect individuals' performance. If employees feel 
injustice, they will lose their motivation to sustain their activities, whereby losses might occur in the organization. According to Adam's Equity Theory, the extent of equity among individuals is accomplished based on the ratio of input imparted to output earned. This helps the employee to develop the perception of fair or unfair behavior within the workplace (Chen, 2008). The harmful impact of corruption occurs when co-workers might experience inequities as they work with employees who are relative to someone in the organization. They feel that an employee has got employment or special favors through nepotism. Besides, due to nepotism, the organization will be less competitive in the market for high-quality candidates and can lose capable executives (Nyukorong, 2014).

The Ethiopian government believes that anti-corruption activities should be supported by scientific research to make them fruitful. However, no previous empirical studies were conducted that gave full information about the reality on the ground. In recent years, diagnostic studies aiming at assessing the level of corruption in Ethiopia have been conducted with the financial support of the development partners. In such a study, the findings of the first phase of the research which focused on the construction sector indicated a high perception of corruption but a low reality. The researchers suggested that it is important to expand the scope of the study to include corruption in health, education, water, land management, justice, telecommunications, and the mining sectors, all relevant to the achievement of the Millennium Development Goals. As the government allocates substantial budgets to these sectors, conducting diagnostic studies and finding out the facts is likely to ensure that the country's financial resources are deployed to the desired objectives and the information gap in this area is filled (Plummer, 2012).

For decades, corruption in Ethiopia has been discussed only at the margins. Perhaps, because many have not experienced corruption as a significant constraint to their lives and businesses or perhaps because a culture of suspicion has inhibited open dialogue, Ethiopia has seen neither the information flow nor the debate on corruption that most other countries have seen in recent years. Based on this, the current study attempted to identify the workplace impacts of nepotism and looked into its relationship with employee disengagement since negative attitudes on the part of employees are likely as a result of such unfair treatment. Specifically, it aimed to assess the contribution of nepotism to the disengagement attitudes of employees in Ethiopian organizations. Hence, it is considered that the results of this study will shed light on the main influences of workplace nepotism that could have input for respective legislators and managers. Furthermore, the study is expected to contribute greatly to the nepotism literature especially for Ethiopia since empirical studies conducted on the topic are very scanty.

In the current study, the first section deals with the literature review about the study variables. The second section covers the methods used to collect the data. The third section presents the results of the study. The final section covers discussion, conclusion, and limitations along with recommendations.

\section{LITERATURE REVIEW}

\subsection{Nepotism}

The word nepotism drives from a Latin word for "nephew" of the bishops in medieval times. It means employing or promoting a person because of his/her kinship regardless of his/her abilities, success, knowledge, educational level, etc. Similarly, Online Oxford English Dictionary defines nepotism as the practice, on the part of the popes or other ecclesiastics, of showing special favor to nephews or other relatives in conferring office. Most empirical studies recognize that hiring or even promoting an employee in an organization due to a connection of kinship, blood affiliate, family ties, friendship, etc. is regarded as nepotism (Araslı, Bavik, and Ekiz, 2006; Aydoğan, 2012; Farahmand, 2013; Özler and Büyükarslan, 2011).

Nepotism is a form of favoritism related to a family connection. Employers are more likely to give privileges to spouses or relatives in the business context. The relatives who benefit from nepotism advance in their careers based on this preferential support instead of their merit. Since nepotism focuses on a hiring factor other than merit, it is considered to be unfair and irrational. In some countries, anti-nepotism policies limit the number of relatives working in the same organization. On the contrary, there may be some pressures on organizations to loosen their strict anti-nepotism policies and further it is believed that there might be a benefit to organizations that practice nepotism. Nepotism is a sensitive issue toward which people usually have negative attitudes in the workplace. It appears during the recruitment, selection, hiring, and career development processes (Fu, 2015; Padgett and Morris, 2005). 
Poor education and lack of experience are thought to result in nepotism. Mulder makes the following definition: “The nepotees' prior work experience and education are two important factors in modern-day situations of nepotism" (2008, p.28). She explains that nepotees are very often seen as unable and incompetent in doing their jobs. But according to Bellow (2003), the situation is quite the opposite. That is because nepotees seem to have a great amount of knowledge and resources due to mostly being raised in business environments; besides, this is experienced in a new nepotism context (cited in Kaye, 2009). Bellow (2003) argues that Nepos would not take a position that she/he is unqualified for as this would only result in huge embarrassment if they fail to accomplish the duty.

In December 2012, a report from the Washington Post revealed different nepotism practices from the District of Columbia and Northern Virginia's Metropolitan Washington Airports Authority (MWAA). The associate general counsel defended the supposed nepotism saying that if the employees are competent enough for their positions then relatives working in the same organization would not be a problem. The U.S. Department of Transportation and Congress pressured the District of Columbia and Northern Virginia's Metropolitan Washington Airports Authority to resolve the acts of nepotism. Reports by V. Kimutai (2013) revealed that in Kenya, a senior manager at the Kenya Pipeline Company accepted that nepotism was deep-rooted in the company. He admitted that all senior and middle-level managers had hired their relatives in different departments. The then engineering manager, Bramwell Wanyalikha agreed his daughter and other senior managers' relatives were employed in the Kenya Pipeline Company. The manager defended by claiming that he did not influence the employment of his daughter as she was picked externally, though the recruitment was internal. Mr. Wanyalikha told the Parliamentary Committee on Energy that he did not participate in the recruiting committee that selected his daughter hence did not influence the issue (Kimutai, 2013). As most organizations encountered in Kenya had no anti-family nepotism policy, relative nepotism is almost a common phenomenon. What matters is simply the act of providing preferred attention, incentive, opportunity, and assignments that is irrelevant to employee performance and achievement (Ombanda, 2018).

There is a lack of information regarding nepotism and its consequences (Padgett and Morris, 2005). Compared to old research, recent studies emphasize the consequences of nepotism and cronyism, which relate to job satisfaction, organizational commitment, ingratiation, performance, morale, inertia, trust, and so on (Khatri, Tsang, and Begley, 2003; Mele, 2009). Prior research on nepotism, on the other hand, has mostly dealt with attitudes toward different forms of nepotism and the effects of hiring family members in the same organization (Padgett and Morris, 2005).

Nepotism has been criticized as being unprofessional (Abdalla, Maghrabi, and Raggad, 1998). Anti-nepotism policies have eliminated preferential treatment in developed countries, while it is part of daily life in developing countries (Boadi, 2000). Nepotism is an unethical problem commonly seen in various organizations. It has been stated that nepotism has serious and negative implications. This may destroy motivation and organizational harmony among the employees, thus yielding unfairness, inefficiency, and weak dedication to work. There is also a potential for conflict when disharmony and dissatisfaction aggravate in the organization. Besides, a general tendency for the unfavored employees in the organization to engage in counterproductive behaviors occurs which may affect the achievement of organizational goals. Such unfavored employees may result in working below their optimal level, increasing absenteeism, or even damaging the organization's properties and belongings (Farahmand, 2013).

Nepotism is an issue that can have an overall adverse effect on turnover, job satisfaction, and organizational citizenship behavior. If leaders make managerial decisions based on personal relationships ignoring an employee's experience and ability within the company, it brings a detrimental effect on the company's overall success (Haywood, 2018). Nepotism also has a connection with employee empowerment, and it demotivates employees and reduces their sense of equity regarding their organization. So, the managers who empower their employees should be very careful in terms of nepotism not to cause any sense of organizational injustice (Seçilmiş and Uysal, 2016). Nepotistic relationships negatively influence a person's performance and motivation. Such relationships may also raise stress levels; and promote the need for employees to seek employment elsewhere (Jaskiewicz, Uhlenbruck, Balkin, and Reay, 2013). Hence, the organization may risk losing some of its best professionals, which may have damaging effects on the bottom line.

Araslı et al. (2006) and Abdalla et al. (1998) indicated that nepotism demotivates and dissatisfies employees in their jobs. Besides, it erodes loyalty and leads to a lack of commitment toward their company. As a result, involvement in work and cooperation among colleagues will also possibly fail. The probability of absenteeism and overall turnover may increase as a result of nepotistic acts which in turn could affect organizational performance (Abdalla et al., 1998). According to Araslı et al. (2006), nepotism in the 
workplace often may direct employees to develop a closer relationship with managers to consolidate their positions instead of showing higher achievement.

\subsection{Disengagement}

Employee disengagement and employee engagement are related. Commonly, these phenomena are studied as being associated with each other and disengagement is often viewed in the context of its negative impact on the organization (Heikkeri, 2010). Maslow, Frager, Fadiman, McReynolds, and Cox (1970) defined work disengagement after examining human needs. But, this construct has been commonly used in the management literature since the 1990s. Kahn (1990) forwarded the theory on work disengagement based on earlier motivational theories. According to Kahn (1990), disengagement is a conscious act of withdrawal and defense. Kahn (1992) further describes the contrast to psychological presence as the psychological absence or alienation from work. Perrin (2011), on the other hand, categorized employees according to their engagement levels: fully engaged, moderately engaged, and highly disengaged from work. As a consequence, disengagement can be defined as a type of cynical attitude and involves distancing oneself from work (Demerouti, Bakker, Nachreiner, and Ebbinghaus, 2002).

Disengagement is characterized by a lack of interest, enthusiasm, and commitment to the job. The disengaged employees are less involved in their business and they might even quit work. According to Schaufeli, Bakker, Van der Heijden, and Prins (2009), disengagement can be described as a negative, lacking work-related state of mind that is signified by a weaker and betrayal personality. For Kahn (1990), disengagement is physical, cognitive or emotional withdrawing or defending by employees during the accomplishment of their work. Kahn (1990, p. 701) gave the following definition for personal disengagement: "Personal disengagement is the simultaneous withdrawal and defense of a person's preferred self in behaviors that promote a lack of connections, physical, cognitive, and emotional absence, and passive, incomplete role performance." As the disengaged employees detach emotionally and cognitively from their tasks, their behavior becomes unresponsive, robotic, and effortless towards their performance (ibid, p. 701).

Previous studies on employee disengagement are lacking as the causes of the construct were not adequately explored (Govindarajo, Kumar, and Ramulu, 2014; Heikkeri, 2010; Pech and Slade, 2006). The information regarding the antecedents of disengagement is also very scanty. It has been focused merely on the measurement and analysis of symptomatic factors instead of causal factors of disengagement. Thus, employee disengagement remained relatively unexplored, hence was limited to its financial impacts (Pech and Slade, 2006).

According to Pech and Slade (2006), Branham (2005), and Kahn (1990), there are three major sources of employee disengagement. Those caused by the external environment, psychological causes, and organizational causes. Organizational causes are concerned with the lack of resources, work complexity, the company's culture, poor administration, bureaucracy, bad working conditions, transformational changes, performance criteria, restructuring of the company, and the like. Other factors leading to disengagement include laziness, poor interpersonal relationships, employees' resource abuse, illness, competency issues, and ethical problems.

Disengaged employees are unhappy and the negative influences that they create may destroy the achievements of engaged workmates (Gallup, 2006). They are disconnected from their jobs, unsatisfied with their personal lives and professional careers, less efficient, less loyal to their organizations, and experience stress and insecurity about their jobs (Heikkeri, 2010; Price, 2007). Disengagement is increasing in workplaces promoting costs and loss of productivity as employee commitment declines (Jauhari, Sehgal, and Sehgal, 2013). Disengaged employees lack enthusiasm and energy as their works are less productive (Inoue et al., 2014; Moody, 2012). It is widely believed that disengaged employees are not strong in problem-solving and do not worry about the realization of organizational vision, purpose, and values. They do not apply their whole efforts to maximize productivity and display a lack of interest in doing so. Besides, disengaged workers are not competitive and they do not provide enough time and energy to make the workplace more effective and conducive (Allam, 2017). It was also found out that 73-81\% of disengaged employees' energy is not utilized in the workplace when they experience injustice (Heikkeri, 2010).

\subsection{The Relationships between Nepotism and Disengagement}

So far, the literature has not presented examples on the direct relationship between nepotism and disengagement; however, other related organizational behavior constructs associated with nepotism were studied. The organizational culture may differ from one organization to another, which is based on philosophies, beliefs, values, expectations, assumptions, attitudes, and norms (Schein, 1990). The nature of public-owned organizations is that these are managed through a yardstick that is bureaucracy, which 
is the sole reason why bureaucratic culture prevails in the public sector organizations. The prevalence of bureaucratic culture means that a top-down approach is used for decision making. This promotes an authoritarian style of management, infrequent communication between employees and decision-makers, employees' waste of time on redundant work and always obeying orders, and the resistance to change (Claver, Llopis, Gascó, Molina, and Conca, 1999). The bureaucratic culture is highly characterized by orders; the transfer of employees and lack of incentives and rewards may lead to a high perception of organizational injustice. Besides, it is associated with rigid organizational policies, strict rules, and regulations. As this kind of culture is not supportive, unfair procedures and organizational politics are experienced (Andrews and Kacmar, 2001; Peters, 2002; Yeşilkağıt, 2004). Antecedents, predictors, motivators, and degrees of work disengagement vary across organizations based on their culture. This is mainly emanated from nepotism and favoritism where the majority of employees face conditions of work overload (Yeşilkağıt, 2004). Injustice, organizational politics, work overload along with the bureaucratic culture can aggravate work disengagement of employees (Aslam, Muqadas, Imran, and Rahman, 2018). However, it is also mentioned that reform in the bureaucracy by creating a clean government and good governance may also be a remedy for getting rid of problems like corruption, collusion, and nepotism (Primanto, Suwitri, and Warsono, 2014).

Nepotism has negative impacts on the morale of employees who work with the relatives of high-level executives and these employees feel that a family member is being promoted and awarded without competence (Abdalla et al., 1998; Asunakutlu and $\mathrm{Avcl}, 2010)$. Employee alienation occurs if workers perceive that recruitment, selection, promotion, work divisions, the delegation of authority, information flow, and relations in the workplace are not handled appropriately. When organizational practices such as execution styles based on nepotism are in place, it is obvious that employees will develop an attitude of alienation towards their respective organizations. In such a situation, organizational relations are deteriorated, interaction among employees is harmed, and general inefficacy in the work atmosphere occurs (Ichniowski, 1988). Consequently, negative influences on job satisfaction (Araslı et al., 2006), job security (Keleş, Özkan, and Bezirci, 2011), and attitudes towards the organization are observed.

Studies on various types of establishments about the topic (Abdalla et al., 1998; Asunakutlu and Avcı, 2010; Büte and Tekarslan, 2010; Ciulla, 2005; Özler, Ergun, and Gümüştekin, 2007) have emphasized the negative impacts of nepotism in terms of the attitudes/behavior towards the work or the organization by employees. Alienation is considered as a negative status which reflects the estranged expectations of individuals from affiliated organizational structures, values, rules, and relations (Şimşek, Çelik, Akgemci, and Fettahlıoğlu, 2006). Such isolation leads to organizational problems such as loss of job satisfaction, low productivity, low motivation, and high job stress, low level of loyalty to the organization, high-level workforce turnover, and quitting (Erkılıç, 2012; Kanungo, 1992). The distance between the worker and the enterprise impedes employees' contribution to the organization.

Favoritism leads to inequality within the workplace and this unfair treatment can impact how employees work together (Khatri and Tsang, 2003). Ford and McLaughlin (1986) stated that this perception of inequities could result in "unfavorable interpersonal relationships between paired employees and their co-workers". A survey conducted with 2,700 samples offered various findings on nepotism. Firstly, nepotism has got a bad image within organizations. Secondly, nepotism has likely affected the behavior and engagement of employees and managers. Moreover, these unfair actions might have eroded the organizational structure. The researcher observed very quickly the recurring themes and commonalities between the seemingly negative reviews. Such organizations are characterized by negative comments, favoritism, limited communication, low salary, poor working conditions, and desperate staff. More comments are associated with a lack of advancement opportunities, shift patterns, no consideration for work-life balance, and working too much overtime (Ewing, 1965).

It is also observed that this subject has not been emphasized in the relevant literature. Remarkably, a significant part of the studies addressing the subject (Abdalla et al., 1994, 1998; Araslı et al., 2006; Asunakutlu and Avcl, 2010; Ciulla, 2005; Ford and McLaughin, 1985; Hutcheson, 2002; Ichniowski, 1988; İyiişleroğlu, 2006; Özler et al., 2007; Padgett and Morris, 2005) are those which have endeavored to define the concept and described the positive and negative aspects. Besides, they made efforts to reveal the relations with various organizational behavior constructs such as job satisfaction, security, and cynicism. Although disengagement is a significant attitude which employees may develop against their organizations with the potential to produce negative consequences both for employees and organizations, it can be said that there is very little research in the literature addressing this topic. 
Within this framework, an empirical study is decided to be carried out to explore the relationship between nepotism and disengagement. The study seeks to contribute to the related literature and propose solutions for the experienced problems of nepotism at work in Ethiopian organizations. Based on the above arguments, it is hypothesized that:

Nepotism positively contributes to disengagement

.Figure 1: Theoretical Model

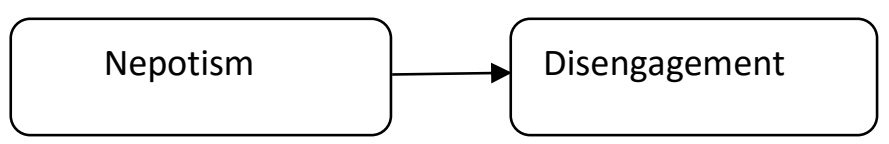

\section{METHODOLOGY}

\section{1 .Participants and Procedure}

Through a convenience sampling method, 26 public and private institutions were selected. The institutions comprised various sectors such as minister offices, county offices, tax and revenue offices, construction, insurance, textile, and other manufacturing and service-providing sectors. The participants were accessed through face-to-face contact and by distributing online soft-copy questionnaires. The respondents were informed that their participation was voluntary and the confidentiality of the responses was ensured.

The demographic characteristics of the sample were diverse as employees were working in various positions and departments. The sample is composed of 255 participants. Of the respondents, $79.2 \%$ were males whereas 20.8 were females; and $43.5 \%$ held at least a university degree. Regarding age, $54.1 \%$ of the participants were younger than 35 years, $32.5 \%$ were from the ages 36 up to 45 , and $13.3 \%$ were older than 45 years. Besides, public and private employees constitute $72.5 \%$ and $27.5 \%$ respectively. Their work experience ranged from beginners to more than 15 years.

\subsection{Instruments}

The instrument used to gather data from the participants in this study had two parts. The first section of the questionnaire includes 11 items for nepotism whereas the second section contains 7 items for disengagement. The original English versions were used to obtain data from the respondents who were fluent in the English language. The 11 items forming the nepotism scale were developed in three different studies. The first group of 7 items was taken from Abdalla et al. (1998). This study showed a coefficient alpha of 0.87. The instrument also consists of 2 items developed by Araslı et al. (2006). The remaining 2 items were taken from Büte (2011). A sample item for the scale is: "Workers in my institution depend on a high-ranking relative."

A 7-item disengagement scale was used to assess the participants' perception of their disengagement attitude in their particular workplace. The items were originally developed by two different groups of authors each contributing a different number of items. The first 2 items (items 1 and 2) were developed by Gaillard and Desmette (2008). The remaining 5 items were developed by Demerouti, Bakker, De Jonge, Janssen, and Schaufeli (2001). The reliability coefficient for the total scale was reported as 0.70 . A sample item for the scale is: "I feel less and less engaged in my work." All of the variables were measured by scales with six-point intervals ranging from "strongly agree" to "strongly disagree."

\section{RESULTS}

\subsection{Factor Analysis and Reliability of the Scales}

Initially, factor analysis and reliability tests of the scales were conducted. Exploratory factor analysis was conducted for the nepotism scale and the result is presented in Table 1 below. Firstly, the Kaiser-Meyer-Olkin measure of sampling adequacy test and Bartlett's Test of Sphericity was conducted. The Kaiser-Meyer-Olkin measure of sampling adequacy was higher than 0.50 (observed as 0.88$)$ and Bartlett test value $\left(X^{2}=1020.996\right.$ and $\left.D F=45\right)$ was significant $(p<0.001)$ for this analysis, showing that it is statistically appropriate to rely on the results of the factor analysis. Then, exploratory factor analysis was conducted using principal component analysis with varimax rotation. The initial analysis revealed two separate factors. The first factor had 8 items that loaded all above 0.5. Factor two consisted of two items which also loaded well above 0.5. Only one item (Item 3 - "Employees of 
this organization always feel that they need someone they know or a friend in a high-level position") was removed because it was loaded with similar weights in two different factors. The variance explained by the two factors was $60.30 \%$.

Then, the reliability of each factor was tested using Cronbach's alpha. The results of the analysis showed that both factors were adequately reliable. Factor one which was named "nepotistic relationships" had a Cronbach alpha of 0.88 and factor two which was named "preferential policy" had an alpha value of 0.69. The results indicated that the instrument that measured the two subdimensions of nepotism is indeed satisfactorily reliable.

Table 1: Factor and Reliability Test Results for the Nepotism Scale

\begin{tabular}{|c|c|c|c|c|c|}
\hline Factors & & Items & $\begin{array}{l}\text { Factor } \\
\text { Loadings }\end{array}$ & $\begin{array}{c}\% \text { of } \\
\text { Variance }\end{array}$ & Reliability \\
\hline \multirow{8}{*}{$\begin{array}{l}\text { Nepotistic } \\
\text { relationships }\end{array}$} & Q8 & $\begin{array}{l}\text { Workers try to meet the demands of other workers who have } \\
\text { relatives in the upper-administration. }\end{array}$ & .83 & \multirow{8}{*}{46.59} & \multirow{8}{*}{.88} \\
\hline & Q7 & $\begin{array}{l}\text { I watch what I say when I talk to colleagues who have relatives } \\
\text { in the upper administration. }\end{array}$ & .77 & & \\
\hline & Q6 & $\begin{array}{l}\text { Department heads are scared of workers who have relations } \\
\text { in the upper-administration. }\end{array}$ & .76 & & \\
\hline & Q9 & $\begin{array}{l}\text { Workers value family members' or acquaintances' benefits } \\
\text { rather than the organization's benefits in general. }\end{array}$ & .76 & & \\
\hline & Q11 & $\begin{array}{l}\text { It is very difficult to remove or to demote people who have } \\
\text { relatives in the upper administration. }\end{array}$ & .72 & & \\
\hline & Q10 & $\begin{array}{l}\text { Preferential treatment causes internal conflicts in my } \\
\text { organization. }\end{array}$ & .71 & & \\
\hline & Q5 & Workers in my institution depend on high-ranking relatives. & .65 & & \\
\hline & Q4 & $\begin{array}{l}\text { Executives are more interested in keeping friends and } \\
\text { acquaintances in good positions than they are in those } \\
\text { employees' performance or the organization's profitability. }\end{array}$ & .65 & & \\
\hline \multirow{2}{*}{$\begin{array}{l}\text { Preferential } \\
\text { policy }\end{array}$} & Q2 & $\begin{array}{l}\text { My organization promotes the practice of preferential } \\
\text { treatment in its hiring and advancement policies. }\end{array}$ & .86 & \multirow{2}{*}{13.71} & \multirow{2}{*}{.69} \\
\hline & Q1 & $\begin{array}{l}\text { The topic of preferential/partial treatment is the basis of } \\
\text { frequent discussion within my workplace. }\end{array}$ & .85 & & \\
\hline
\end{tabular}

Exploratory factor analysis was also conducted for the disengagement scale (see Table 2 below). Firstly, the Kaiser-Meyer-Olkin measure of sampling adequacy test and Bartlett's Test of Sphericity was conducted. The Kaiser-Meyer-Olkin measure of sampling adequacy was higher than .50 (observed as .817 ) and Bartlett test value $\left(X^{2}=648.051\right.$ and $D F=21$ ) was significant $(p<0.001)$ for this analysis, showing that it is statistically appropriate to rely on the results of the factor analysis. Then, exploratory factor analysis was conducted using principal component analysis with varimax rotation. The initial analysis revealed a single factor. The factor has 7 items that loaded all above .50 . 
Later, the reliability of the emerged single factor was tested using Cronbach's alpha. The results of the analysis showed that the factor was adequately reliable revealing a Cronbach alpha of .83. The name of the factor remained unchanged ("disengagement") since only a single factor was obtained. The variance explained by disengagement was $50.72 \%$.

Table 2: Factor and Reliability Test Results for the Disengagement Scale

\begin{tabular}{|c|c|c|c|c|c|}
\hline Factor & & Items & $\begin{array}{l}\text { Factor } \\
\text { Loadings }\end{array}$ & $\begin{array}{c}\% \text { of } \\
\text { Variance }\end{array}$ & Reliability \\
\hline \multirow{7}{*}{ Disengagement } & Q7 & I feel less and less engaged in my work. & .79 & \multirow{7}{*}{50.72} & \multirow{7}{*}{.83} \\
\hline & Q5 & $\begin{array}{l}\text { Lately, I tend to think less at work and do my job almost } \\
\text { mechanically. }\end{array}$ & .78 & & \\
\hline & Q6 & I do not find my work to be a positive challenge. & .74 & & \\
\hline & Q4 & $\begin{array}{l}\text { It happens more and more often that I talk about my work } \\
\text { negatively. }\end{array}$ & .72 & & \\
\hline & Q2 & I consider work not to be a very important part of my life. & .71 & & \\
\hline & Q1 & Doing my job well is not very important to me. & .69 & & \\
\hline & Q3 & I rarely find new and interesting aspects of my work. & .53 & & \\
\hline
\end{tabular}

\subsection{Regression Analysis}

Simple linear regression analysis was conducted to assess the relationship between nepotism and disengagement. Nepotism is the independent variable and has two sub-dimensions: Nepotistic Relationships and Preferential Policy. Disengagement is the dependent variable that was found to be a uni-dimensional construct. The results of the regression analysis are presented in Table 3 below.

As can be seen from the table below, there is a significant relationship between the sub-dimension of nepotistic relationships and disengagement. Nepotistic relationships positively predicted disengagement since the simple linear regression model established between the two variables is significant $(\beta=.34 ; F=33.74 ; p=0.000)$. The result indicates that $11.8 \%\left(R^{2}=.118\right)$ of the disengagement attitude is explained by nepotistic relationships. However, the model established for the sub-dimension of preferential policy and disengagement was not significant $(\beta=.04 ; F=.37 ; p=.55)$. The result shows that preferential policy is not a significant predictor of employees' disengagement attitude.

Thus, the study hypothesis that states "Nepotism positively contributes to disengagement" is partially supported.

Table 3: Regression Analysis of the Relationship between Nepotism and Disengagement

\begin{tabular}{|l|c|c|c|c|c|c|c|}
\hline & \multicolumn{3}{|c|}{ Model Summary } & Anova & \multicolumn{3}{c|}{ Standardized Coefficients } \\
\hline Models & $\mathbf{R}$ & $\mathbf{R}^{\mathbf{2}}$ & Adjusted R & $\mathbf{F}$ & $\mathbf{B}$ & $\mathbf{T}$ & $\mathbf{P}$ \\
\hline $\begin{array}{l}\text { Disengagement } \\
\text { with nepotistic } \\
\text { relationships }\end{array}$ & .34 & .118 & .114 & 33.74 & .34 & 5.81 & .000 \\
\hline $\begin{array}{l}\text { Disengagement with } \\
\text { preferential policy }\end{array}$ & .04 & .00 & -.00 & .37 & .04 & .60 & .55 \\
\hline
\end{tabular}

\section{DISCUSSION, CONCLUSION, LIMITATIONS, AND RECOMMENDATIONS}

\subsection{Discussion}

Nepotism is an unethical problem in an organization that has strong negative impacts over periods. It erodes the organizational unity and motivation of the workers, thereby causing unfairness, weak dedication to work, and inefficiency. There is also a possibility for conflict when dissatisfaction and disharmony are experienced in the organization. The unfavored employees may 
be inclined to engage in counter-productive behaviors that could affect the realization of the organizational goals. Such demoralized employees may not work full-heartedly and may frequently experience absenteeism or may even damage organizational belongings (Farahmand, 2013).

It is in this way that the impact of nepotism on employees' work disengagement becomes important. In the past, most nepotism theories and empirical studies had primarily centered on the outcomes which were considered relevant to the employer. From now on, it is expected that employee-related consequences will find more place in the related literature. The present study makes an effort to contribute in this respect.

The main purpose of the current study was to investigate the contribution of nepotism to employees' disengagement attitudes. The overall results of the analysis partially supported the proposed hypothesis. The relationship between nepotistic relationships and disengagement was supported. However, no significant relationship between preferential policy and disengagement was found. In the following sections, the results of the analysis are discussed in comparison with the previous related empirical findings.

In this study, primarily, it was proposed that nepotism would have a positive contribution to disengagement. In terms of nepotistic relationships, the hypothesis was supported. This was consistent with some findings. For example, a study conducted by Araslı et al. (2006) in hotels indicated that working in an unfair organization makes employees dissatisfied and demoralized. This might force them to be disloyal and uncommitted to the organization. Such an issue may affect their job interest, work involvement, cooperation, and coordination with their co-workers in their business. These may result in less productivity, absenteeism, and turnover as nepotism is based on unfair advancement. Moreover, nepotism causes other psychological problems such as disappointment, frustration, stress, and negative word of mouth in the hotel or may compel them to change their jobs when possible.

Similar results were obtained in another study as follows. The results showed that nepotism dominated human resource policies within organizations in Cyprus. Here, bank employers generally preferred to hire, reward or promote their relatives or friends. By doing so, they did not seem to value knowledge, skills, abilities, and training of applicants for jobs. Instead, employers commonly considered blood ties, close friendships, and ideological inclinations. Especially, the key ranks such as managerial and supervisory positions presented very limited job opportunities in these workplaces (Araslı and Tümer, 2008). Therefore, such a widespread occurrence may be expected to harm employees' connection with the organization and work.

There were also other study results obtained in Turkey which revealed the nature and organizational effects of nepotism as follows. There was a general perception shared by employees that nepotism is widely exercised during job promotion in organizations (Büte and Tekarslan, 2010). It seems that personal relationships were considered to be the driving force for promotion instead of any given standards in the organizational structures active in the community. This appears to reflect the characteristics of the collectivist culture where the relationships in the organization may be more inclined towards relations with the family, kith and kin, friends, and partiality. On the other hand, the assessed negative effects of nepotism have their reflections on the trust in the organization (Keleş et al., 2011) and job satisfaction of employees (Asunakutlu and Avcl, 2010).

Organizational studies reveal that job specifications, levels of compensation in the workplace, and equity among employees are used to determine workers' earnings. Besides, the level of rewards is determined by individual contributions using bonus schemes based on employees' qualifications, past experiences, skills, and bargaining power. Bellow (2003) stated that Human Resource Management must ensure that organizational policies are fair and equal. However, in a real sense, an individual's salary is observed to be increased by nepotism depending on the employee's relationship with the managers within or outside the organization (Goldberg, 1982). It was seen that earning undeserved benefits in an unethical way through blood ties or interpersonal relationships has been common in organizations (Boadi, 2000). When it comes to job recruitment and promotion, partiality is displayed in terms of favoring relatives and friends instead of taking employee qualification and vitality to the organization into account. Consequently, others are influenced negatively. Moreover, studies indicate that nepotism in staff may reinforce conflicts of interest. The result is the negative impacts of these practices on employees.

A study by Breuer, Nieken, and Sliwka (2010) showed that organizations were characterized by the diversity of people from various backgrounds and outlooks. Although such a human capital exists, nepotism poses a powerful threat to the growth of the company and individual career progress. Especially in the unemployment world, nepotism may be quite demoralizing when one finds out that others are easily getting the work he/she deserves, all because they know someone in the upper position. Unfortunately, this practice may be widespread in almost all private and public organizations in some developing countries. The biggest shortcoming 
of office nepotism is that it leaves aside qualified human resource that would have greatly impacted on performance, and it promotes the undeserving few personalities. It should finally be noted that workplace nepotism commonly adheres to the hiring of people with fewer qualifications, skills, and experiences in positions based on their relationship with the higher administration (Allen and Meyer, 1990). Therefore, it should not be surprising to find out that the bond between the employees and the organization gets weakened.

\subsection{Conclusion}

Nepotism harms personal and social relationships by impeding employees' workplace engagement. There is significant research evidence that nepotism undermines organizations and the employees who take part in the service. Nepotism hampers effective competition for the superior positions and impedes high performers' career progress in workplaces. This phenomenon can be viewed as a form of discrimination through which relatives or friends are recruited or promoted not because of their qualifications and abilities, but only because they have blood ties or networks with the managers of the organization. Especially, in developing collective societies, nepotism which is part of the societal culture is pervasive in an organization. Such a situation alienates employees from their work. Employees' reluctance in developing ties with their work may, in turn, result in multi-faceted organizational problems that affect the efficiency of business activities. Generally, it is a common problem in almost all organizations and it affects the morale, climate, and overall performance of the organization. Ethiopia as a developing country is no exception to the aforementioned impacts of nepotism. Since nepotism is considered a form of corruption that adversely affects organizational and economic development, corrective actions must be taken to combat it.

\subsection{Limitations}

In the current study, primarily the relationship between nepotism and disengagement were investigated. Though the study added significant inputs to the existing body of knowledge regarding the relationship between nepotism and disengagement, some potential limitations have to be acknowledged. When overall employees in Ethiopia were considered, the sample size was small which may lead to possible bias. As a matter of chance, in the organizations contacted, most of the participants were males; hence, gender participation was not balanced. In this study, it was attempted to assess the relationship of nepotism with a single variable disengagement; hence, potential intervening and moderating variables were not considered. This study was conducted in the organizations of three cities, namely, Addis Ababa, Adama, and Shashamane in a single country, Ethiopia. However, a comparison between organizations in different countries could not be realized. Due to limited time, the data collection method employed was convenience sampling which may affect the representativeness of the sample. The cross-sectional design of the current study, on the other hand, does not permit to make causal inferences. The present study also lacked an intensive qualitative dimension in data collection to elicit more information with focus group discussions and interviews. Moreover, the study required the respondents to rate themselves on nepotism and disengagement. The results presented may have been distorted as some of the respondents may be beneficiaries of nepotism.

\subsection{Recommendations}

The findings of the study revealed that nepotism had adverse effects on employees' engagement due to advantages provided for privileged persons. The results obtained from this study are vital for the employers and managers of the organizations in Ethiopia. Considering this issue, anti-nepotistic laws should be inculcated to the labor laws and properly enforced by the respective organizational bodies. Nepotism leads to alienation and impedes departmental teamwork and overall organizational successes; therefore, the nepotistic culture should be discouraged. Moreover, to minimize the impact of nepotism in respective organizations, anti-nepotistic rules and procedures should be enforced strictly to control preferential treatments during the induction and promotion of the employees.

Based on the limitations of the current study, the following points may be recommended. The future studies should include the client's point of view instead of a single employee's side to assess the issue complementarily. It may be suggested for future studies to adopt a longitudinal design that would help establish causal relationships. Besides, the next studies may use in-depth interviews as an alternative approach for providing richer insights into nepotism and disengagement relationships. The replication studies in other Ethiopian cities should be conducted for the cross-validity and generalizability. Also, the moderating roles of personality types on the relationship between nepotism and disengagement may be explored to obtain a more comprehensive understanding of the topic. 


\section{REFERENCES}

Abdalla, H. F., Maghrabi, A. S., \& Al-Dabbagh, T. H. (1994). Research Note: Assessing the Effect of Nepotism on Human Resource Managers, International Journal of Manpower, 15(1), 60-67. Permanent link to this document: http://dx.doi.org/10.1108/EUM0000000003933

Abdalla, H. F., Maghrabi, A. S., \& Raggad, B. G. (1998). Assessing the Perceptions of Human Resource Managers toward Nepotism: A Cross-Cultural Study. International Journal of Manpower, 19(8), 554-570.

Ahmadi, M. (2009). Assessment of the Causes of Employees' Adherence to Municipal Corruption in Esfahan (Isfahan Municipality). Unpublished Master's Thesis, Tehran University.

Allam, Z. (2017). Employee Disengagement: A Fatal Consequence to Organization and its Ameliorative Measures. International Review of Management and Marketing, 7(2), 49-52. ISSN: 2146-4405, Available at https: www.econjournals.com.

Allen, N. J., \& Meyer, J. P. (1990). The Measurement and Antecedents of Affective, Continuance and Normative Commitment to the Organization. Journal of Occupational \& Organizational Psychology, 63, 18-38.

Andrews, M. C., \& Kacmar, K. M. (2001), Discriminating among Organizational Politics, Justice, and Support. Journal of Organizational Behavior, 22(4), 347-366.

Araslı, H., \& Tümer, M. (2008). Nepotism, Favoritism, and Cronyism: A Study of Their Effects on Job Stress and Job Satisfaction in the Banking Industry of North Cyprus. Social Behavior and Personality, 36(9), 1237-1250.

Araslı, H., Bavik, A., \& Ekiz, E. H. (2006). The Effects of Nepotism on Human Resource Management: The Case of Three, Four, and Five Star Hotels in Northern Cyprus. The International Journal of Sociology and Social Policy, 26, 295-308.

Aslam, U., Muqadas, F., Imran, M. K., \& Rahman, U. U. (2018). Investigating the Antecedents of Work Disengagement in the Workplace. Journal of Management Development, 37( 2), 149-164. DOI: 10.1108/JMD-06-2017-0210

Asunakutlu, T., \& Avcı, U. (2010). Aile İşletmelerinde Nepotizm Algısı ve İş Tatmini İlişkisi Üzerine bir Araştırma. Süleyman Demirel Üniversitesi iktisadi ve Idari Bilimler Fakültesi Dergisi, 15(2), 93-109.

Aydoğan, I. (2012). The Existence of Favoritism in Organizations.n African Journal of Business Management, 6(12), 4577-4586. Available online at http://www.academicjournals.org/AJBM DOI:10.5897/AJBM11.2692 ISSN 1993-823

Bellow, A. (2003). In Praise of Nepotism: A Natural History. Garden City, NY: Doubleday.

Boadi, E. G. (2000). Conflict of Interest, Nepotism, and Cronyism. In J. Pope (ed.), Confronting Corruption: The Elements of a National Integrity System (pp. 195-204). TI SOURCE Book 2000.

Branham, L. (2005). The 7 Hidden Reasons Employees Leave: How to Recognize the Subtle Signs and Act before It's Too Late. Saranac Lake, NY, USA: AMACOM.

Breuer, K., Nieken, P., \& Sliwka, D. (2010). Social Ties and Subjective Performance Evaluations: An Empirical Investigation. IZA DP (Discussion Papers from Institute of Labor Economics) No. 4913.

Büte, M. (2011). Perceived Nepotism and Its Relation to Job Satisfaction, Negative Word of Mouth, and Intention to Quit. Electronic Journal of Social Sciences, 10 (36), 187-203. ISSN 1304-0278.

Büte, M., \& Tekarslan, E. (2010). Nepotizmin Çalışanlar Üzerine Etkileri: Aile İşletmelerine Yönelik Bir Saha Araştırması. Ekonomik ve Sosyal Araştırmalar Dergisi, 6(1), 1-21.

C. J. Edgardo, \& S. Pradhan (eds.). (2007). The Many Faces of Corruption: Tracking Vulnerabilities at the Sector Level (English). Washington, DC: World Bank. http://documents.worldbank.org/curated/en/571831468315566390/The-many-faces-of-corruption-tracking-vulnerabilities-at-thesector-level

Chen, L. (2008). Job Satisfaction among Information System (IS) Personnel. Computers in Human Behavior, 24(1), 105-118.

Ciulla, J. B. (2005). The State of Leadership Ethics and the Work that Lies Before Us. Business Ethics: A European Review, 14(4), 323-335.

Claver, E., Llopis, J., Gascó, J. L., Molina, H., \& Conca, F. J. (1999). Public Administration: From Bureaucratic Culture to Citizen-Oriented Culture. International Journal of Public Sector Management, 12(5), 455-464.

Demerouti, E., Bakker, A. B., de Jonge, J., Janssen, P. P. M., \& Schaufeli, W. B. (2001). Burnout and Engagement at Work as a Function of Demands and Control. Scandinavian Journal of Work, Environment, and Health, 27(4), 279-286. 
Demerouti, E., Bakker, A. B., Nachreiner, F., \& Ebbinghaus, M. (2002). From Mental Strain to Burnout. European Journal of Work \& Organizational Psychology, 11(4), 423-441.

Erkılıç, E. (2012). Örgütsel Stresin Örgütsel Yabancılaşmaya Etkisi. Unpublished Master's Thesis. Afyonkarahisar: Afyon Kocatepe Üniversitesi, Sosyal Bilimler Enstitüsü.

Ewing, D. W. (1965). Is Nepotism So Bad? Harvard Business Review, 43(1), 22-160.

Farahmand, N. (2013). Impact of Nepotism on Turnover Intention and Service Recovery Performance: The Case of Private Hospitals in TRNC. Unpublished Master's Thesis. Gazimağusa, North Cyprus: Eastern Mediterranean University, Institute of Graduate Studies and Research.

Ford, R., \& McLaughin, F. (1985). Nepotism. Personnel Journal, 64, 57-61.

Ford, R., \& McLaughlin, F. (1986). Nepotism: Boon or Bane. Personnel Administrator, 31, 79-89.

Fu, I. (2015). Favoritism: Ethical Dilemmas Viewed through Multiple Paradigms. The Journal of Values-Based Leadership, 8(1), Article 6, 1-7. Retrieved from http://scholar.valpo.edu/jvbl/

Gaillard, M., \& Desmette, D. (2008). Intergroup Predictors of Older Workers' Attitudes towards Work and Early Exit. European Journal of Work and Organizational Psychology, 17(4), 450-481. DOI: 10.1080/13594320801908564

Gallup Organization. (2006). Feeling Good Matters in the Workplace. Gallup Management Journal. http://gmj.gallup.com/content/20770/GallupStudy-Feeling-Good-Matters - Workplace.aspx

Goldberg, M. S. (1982). Discrimination, Nepotism, and Long-Run Wage Differentials. The Quarterly Journal of Economics, 97(2), 307-319.

Govindarajo, N. S., Kumar, D. M., \& Ramulu, S. S. (2014). Why Workers Disengage? Factors from 'Head' or 'Heart' to be Tagged on? Asian Social Science, 10(17), 108-119.

Haywood, L. W. (2018). A Family Affair: A Quantitative Study on the Impact of Nepotism in the Workplace. Unpublished Doctoral Dissertation. Prescott, Arizona: North Central University Graduate Faculty of the School of Business and Technology Management. ProQuest Number: 10822998 Published by ProQuest LLC.

Heikkeri, E. (2010). Roots and Consequences of the Employee Disengagement Phenomenon. Unpublished Master's Thesis. Lappeenranta: Saimaa University of Applied Sciences, Business Administration.

Hutcheson, O. J. (2002). Negotiating Nepotism. Financial Planning, 75-76.

Ichniowski, T. (1988). The New Nepotism: Why Dynasties are Making a Comeback. Business Week, 31(4), 106-109.

Inoue, A., Kawakami, N., Tsutsumi, A., Shimazu, A., Miyaki, K., Takahashi, M., Kurioka, S., Eguchi, H., Tsuchiya, M., Enta, K., Kosugi, Y., Sakata, T., \& Totsuzaki, T. (2014). Association of Job Demands with Work Engagement of Japanese Employees: Comparison of Challenges with Hindrances. PLOS One Journal, 9(3), 1-8. http://dx.doi.org/10.1371/journal.pone.0091583

İyiişleroğlu, S. C. (2006). Aile Şirketleri: Adana ve Çevresinde Faaliyet Gösteren Aile Şirketlerinde Nepotizm Uygulamasinin Tespitine Yönelik Bir Araştırma. Unpublished Master's Thesis. Adana: Çukurova Üniversitesi, Sosyal Bilimler Enstitüsü.

Jauhari, V., Sehgal, R., \& Sehgal, P. (2013). Talent Management and Employee Engagement: Insights from InfoTech Enterprises Ltd. Journal of Services Research, 13(1), 161-186. Retrieved from https://www.questia.com/library/p62525/journal-of-services-research

Jaskiewicz, P., Uhlenbruck, K., Balkin, D. B., \& Reay, T. (2013). Is Nepotism Good or Bad? Types of Nepotism and Implications for Knowledge Management. Family Business Review, 26(2), 121-139.

Kahn, W. A. (1990). Psychological Conditions of Personal Engagement and Disengagement at Work. Academy of Management Journal, 33(4), 692724.

Kahn, W. A. (1992). To be Fully There: Psychological Presence at Work. Human Relations, 45(4), 321-349.

Kanungo, R. N. (1992). Alienation and Empowerment: Some Ethical Imperatives in Business. Journal of Business Ethics, 6, $413-422$. http://dx.doi.org/10,1007/BF00870553

Kaye, K. (2009). Book Review: Bellow, A. (2003). In Praise of Nepotism: A Natural History. Garden City, NY: Doubleday. Family Business Review, 22(2), 181-184. Downloaded from fbr.sagepub.com at University of Sussex Library on 2015/08/15, DOI: 10.1177/089448650

Keleş, H. N., Özkan, T. K., \& Bezirci, M. (2011). A Study on the Effects of Nepotism, Favouritism, and Cronyism on Organizational Trust in the Auditing Process in Family Businesses in Turkey. International Business and Economics Research Journal, 10(9), 9-16. https://doi.org/10.19030/iber.v10i9.5622 
Khatri, N., \& Tsang, E. W. K. (2003). Antecedents and Consequences of Cronyism in Organizations. Journal of Business Ethics, $43,289-303$.

Kimutai, L. V. (2013, July 26). Standard Newspaper.

Maslow, A. H., Frager, R., Fadiman, J., McReynolds, C., \& Cox, R. (1970). Motivation and Personality (Vol 2). New York: Harper \& Row.

Mele, D. (2009). The Practice of Networking: An Ethical Approach. Journal of Business Ethics, 90(4), 487-503.

Moody, V. J. (2012). Examining Leadership Styles and Employee Engagement in the Public and Private Sectors. Unpublished Doctoral Dissertation. Retrieved from ProQuest Dissertations and Theses database (UMI No. 3535727).

Mulder, B. K. (2008). Risking the Business or Reading the Benefits: The Antecedents and Consequences of Nepotism. ProQuest Dissertations \& Theses (PQDT) Database. Retrieved from http://gradworks.umi.com/

Nyukorong, R. (2014). Corruption, Nepotism or the "Whom You Know" Factor and How it Affects Recruitment in the Banking Sector of Ghana. Developing Country Studies, 4(24), 38-53. ISSN 2224-607X (Paper) ISSN 2225-0565 (Online), www.iiste.org

Ombanda, P. O. (2018). Nepotism and Job Performance in the Private and Public Organizations in Kenya. International Journal of Scientific and Research Publications, 8(5), 474-494.

Özler, D. E., \& Büyükarslan, A. (2011). The Overall Outlook of Favoritism in Organizations: A Literature Review. International Journal of Business and Management Studies, 3(1), 275-285.

Özler, H., Ergun, D. Ö., \& Gümüştekin, G. E. (2007). Aile İşletmelerinde Nepotizmin Gelişim Evreleri ve Kurumsallaşma. Selçuk Üniversitesi Sosyal Bilimler Enstitüsü Dergisi, 17, 437-450.

Padgett, M. Y., \& Morris, K. A. (2005). Keeping it "All in the Family:" Does Nepotism in the Hiring Process Really Benefit the Beneficiary? Journal of Leadership and Organizational Studies, 11(2), 34-45.

Pech, R. J., \& Slade, B. W. (2006). Employee Disengagement: Is There Evidence of a Growing Problem? Handbook of Business Strategy, 7(1), 2125.

Perrin, T. (2011). Global Workforce Study 2007-2008: Closing the Engagement Gap - A Road Map for Driving Superior Business Performance. London: Towers Watson.

Peters, G. (2002). The Politics of Bureaucracy. London: Routledge.

Plummer, J. (ed.). (2012). Diagnosing Corruption in Ethiopia: Perceptions, Realities, and the Way Forward for Key Sectors. Washington, D.C.: World Bank.

Price, A. (2007). Human Resource Management in a Business Context ( ${ }^{\text {rd }}$ ed.). London: Thomson.

Primanto, A., Suwitri, S., \& Warsono, H. (2014). Bureaucratic Reform: A Way to Eliminate Corruption, Collusion, and Nepotism Practices in Indonesia. International Journal of Economics, Commerce and Management, 2(10), 1-23.

Schaufeli, W., Bakker, A. B., van der Heijden, F. M., \& Prins, J. T. (2009). Workaholism among Medical Residents: It is the Combination of Working Excessively and compulsively that Counts. International Journal of Stress Management, 16, 249-272. DOI:10,1037/a0017537

Schein, E. H. (1990). Organizational Culture: What It Is and How to Change It? In P. Evans, Y. Doz, \& A. Lorent (eds.), Human Resource Management in International Firms (pp. 56-82). London: Palgrave Macmillan.

Seçilmiş, C., and Uysal, D. (2016). The Moderating Role of Nepotism in the Effect of Employee Empowerment on Perceptions Regarding Organizational Justice at Hospitality Organisations. International Journal of Business and Management Invention, 5(9), 65-76. ISSN (Online): 2319 -8028, ISSN (Print): 2319 - 801X, www.ijbmi.org

Şimşek, M. Ş., Çelik, A., Akgemci, T., \& Fettahlıŏlu, T. (2006). Örgütlerde Yabancılaşmanın Yönetimi Araştırması. Selçuk Üniversitesi Sosyal Bilimler Enstitüsü Dergisi, 15, 569-587.

Yeşilkağıt, K. (2004). Bureaucratic Autonomy, Organizational Culture, and Habituation: Politicians and Independent Administrative Bodies in the Netherlands, Administration and Society, 36(5), 528-552. 